\title{
IDENTIFIKASI KEMAMPUAN PEMECAHAN MASALAH MAHASISWA CALON GURU IPA PADA PENYELESAIAN SOAL TITRASI
}

\author{
Wiwin Puspita Hadi ${ }^{1}$ \\ ${ }^{1}$ Program Studi Pendidikan IPA Universitas Trunojoyo Madura Jln. Raya Telang PO.BOX 2 \\ Kamal Bangkalan
}

\begin{abstract}
Abstrak - Penelitian ini bertujuan untuk mengetahui kemampuan pemecahan masalah mahasiswa calon guru IPA dalam menyelesaikan soal titrasi. Materi ini diberikan pada mata kuliah analisis senyawa kimia. Subjek penelitian ini adalah mahasiswa semester 4 tahun akademik 2018/2019 sebanyak 44 mahasiswa program studi pendidikan IPA. Metode menggunakan analisis kuantitatif deskriptif. Data diperoleh dengan melalui tes essay tentang titrasi sebanyak dengan jawaban menggunakan sistematika dari Polya. Hasil jawaban mahasiswa dianalisis dan dikatogerikan berdasarkan jawaban yang dituliskan. Kemampuan pemecaham masalah masih tergolong rendah karena berbagai faktor. Kemampuan pemecahan masalah dari mahasiswa masih harus ditingkatkan dengan memberikan latihan dan pemberian model pembelajaran yang mampu meningkatkan kemampuan pemecahan masalah mahasiswa.
\end{abstract}

Kata kunci: calon guru IPA, pemecahan masalah, titrasi.

\begin{abstract}
This study aimed to determine the problem solving abilities of pre-service science teachers in solving titration problems. Lecturer gave this material in the course of the analysis of chemical compounds. The subjects of this study were the fourth grade students of the 2018/2019 academic year as many as 44 students of natural science education study program. The method used kuantatif deskriptive analysis. Data collected from titration problems used systematic problem solving from Polya. The results of student's answers were analyzed and categorized. The problem solving ability were poor. The conclusion showed that the problem solving abilities of students must still be improved by providing exercises and providing learning models that are able to improve students' problem solving abilities.
\end{abstract}

Keywords: pre-sevice science teacher, problem solving, titration.

\section{PENDAHULUAN}

Era disrupsi telah menjadi suatu tantangan yang harus dihadapi oleh segenap bangsa. Pendidikan merupakan bagian yang tidak terpisahkan dalam rangka menghadapi tantangan di era tersebut. Pendidikan diharapkan dapat mencetak generasi yang mampu berpikir kreatif dan adaptif menghadapi berbagai persoalannya melalui pembelajaran aktif (Sumarni, dkk 2019). Pembelajaran aktif yang dilakukan untuk mengajarkan konsep dasar dan pengetahuan merupakan dasar dalam pembelajaran, sedangkan keterampilan proses sains terjadi menggunakan logika untuk menemukan jawaban dari pertanyaan yang terjadi dalam kehidupan sehari-hari. Keterampilan proses tidak hanya digunakan untuk menyelesaikan masalah tetapi dapat diplikasikan dalam berbagai situasi dalam kehidupan. Proses ini membutuhkan kemampuan berpikir kritis dan

${ }^{1}$ Corresponding author: Program Studi Pendidikan IPA Universitas Trunojoyo Madura 69162, Indonesia. Email: wiwin.puspitahadi@trunojoyo.ac.id 
pemecahan masalah. Oleh karena itu sangat penting bagai calon guru IPA untuk menguasai berbagai kemampuan dalam pembelajaran khususnya kemmpaun pemecahan masalah untuk mengoptimalkan proses pembelajaran IPA di kelas (Nurita, 2017). Aktifitas pemecahan masalah merupakan aktifitas berpikir yang termasuk dalam empat komponen kemampuan berpikir tingkat. Pemecahan masalah didefinisikan sebagai keterampilan mengidentifkasi masalah menggunakan strategi nonautomatic sehingga peserta didik akan mempu menyelesaikan masalah sendiri dan bekerja dengan lebih efektif (Nugroho, 2018). Kemampuan pemecahan masalah merupakan suatu landasan berpikir dalam kompleksitas. Orang yang mempunyai kemampuan pemecahan masalah yang tinggi akan mempunyai kemampuan untuk menyelesaikan masalah kompleks daripada orang yang mempunyai tingkat intelegensi yang tinggi (Agnihotri, 2015). Pemecahan masalah merupakan proses penemuan solusi atau permasalahan kompleks yang merupakan bagian dari keterampilan berpikir.

Tahapan dalam pemecahan masalah meliputi : pemahaman masalah (understanding the problem) yaitu dengan memperhatikan secara jelas data apa saja yang diperlukan; perencanaan (devising a plan) yaitu harus mampu memikirkan langkah-langkah penting dan saling terkait agar dapat menemukan ide untuk menyelesaikan masalah, kemampuan berpikir yang tepat hanya dapat dilakukan jika peserta didik telah dibekali pengetahuan yang cukup; tahap selanjutnya adalah pelaksanaan rencana (carrying out the plan) pada tahap ini siswa melakukan perhitungan sesuai dengn konsep yang seusia dan mamsukkan data-data yang sesuai dengan rencana pemecahan masalah, peserta didik melakukan langkah-langkah rencana yang telah diterapkan dan mampu memeriksa setiap langkah penyelesaian dan membuktikan bahwa yang dilakukan sudah benar. tahap terakhir adalah pemeriksaan kembali (looking back) pada tahap peserta didik harus berusaha memeriksa kembali dengan teliti hasil yang telah dikerjakan dengan adanya tahap ini peserta didik dapat memperkuat pengetahuannya dan mengembangkan kemampuan mereka untuk menyelesaikan masalah (Polya, 1945).

Kemampuan pemecahan masalah sangat penting untuk dikembangkan berpengaruh terhadap kemampuan yang lain seperti dengan keterampilan proses sains (Cun\&Yu, 2010); sikap entrepreneurship (Kim,dkk 2018).Selain itu kemampuan pemecahan masalah ini sangat penting untuk kegiatan akademik dan kehidupan sehari-hari (Wismath, 2014). Berbagai upaya telah dilakukan untuk meningkatkan kemampuan pememcahan masalah antara lain adalah dengan bar modeling (Widyasari, 2018), pembelajaran berbasis konteks ( Kuang, 2015), Pembelajaran ilmu sosial (Nasriah, 2017), dan strategi MAUVE (Rikardus, 2018).

Persoalan yang dihadapi adalah masih rendahnya kemampuan pemecahan masalah disebabkan oleh kurangnya pengetahuan, selain itu dalam upaya untuk mengatasi masalah dipengaruhi juga oleh motivasi dan aspek emosiaonal (Dostal, 2015). Penggunaan kurikulum sangat berpengaruh terhadap kemampuan pemecahan masalah (Davis,dkk 2019). Upaya meningkatkan kemampuan pemecahan masalah harus dilakukan secara berkesinambungan yang melibatkan peserta didik secara keseluruhan.

Pembelajaran melibatkan kemampuan peserta didik dalam mengembangkan keaktifannya meliputi pembelajaran aktif yang diharapkan menstimulus peserta didik melakukan observasi, investigasi dan percobaan (Hidayati, 2018). Pembelajaran kimia melibatkan tiga dimensi utama yaitu konsep dasar, keterampilan proses sains, dan sikap ilmiah yang diaplikasikan dalam kegiatan pembelajaran yang teintegrasi dalam proses ilmiah (Nurita, 2018). Kemampuan pemecahan masalah merupakan kemampuan penting yang harus dimiliki, salah satunya dalam kemampuan untuk menyelesaikan soal dalam bentuk perhitungan. Sesuai dengan terori Polya yang menyatalan bahwa kemampuan pemecahan masalah akan menstimulasi mereka untuk menemukan pengetahuan baru melalui pembelajaran aktif. Kemampuan pemecahan masalah meliputi tahap kemampuan memahami masalah yang meliputi identifikasi data yang diketahu, data yang ditanyakan, data penting dan dan kecukupan data; tahap selanjutnya adalah menentukan strategi dan melaksanalan strategi; menerapkan perhitungan matematis dan tahap terakhir adalah 
menginterpretasikan permasalahan utama dan cek kebenaran dari solusi yang telah diberikan (Widyasari, 2018).

Berdasarkan karakteristik dari ilmu kimia, pembelajaran kimia sudah seharusnya dilaksanakan dalam rangka peningkatan keterampilan berpikir melalui melalui pemecahan masalah yang berkaitan dengan fenomena kimia. Penyelesaian masalah tentang fenomena kimia dalam pembelajaran akan dapat memberikan mahasiswa beberapa keuntungan. Pertama, mahasiswa dapat lebih memahami adanya hubungan yang erat antara kimia dengan situasi, kondisi, dan kejadian di lingkungan sekitarnya. Kedua, mahasiswa akan terampil dalam menyelesaikan masalah secara mandiri melalui proses berpikir tingkat tinggi. Konsep asam-basa merupakan konsep yang mendasari materi titrasiasam-basa. Jika konsep asam-basa yang mendasarimateri titrasi asam-basa belum dipahami mahasiswa, maka mahasiswa cenderung mengalami kesulitan untuk mema-hami materi titrasi asam-basa Kemampuan pemecahan masalah dapat dilatihkan dan dibekalkan kepada mahasiswa calon guru sehingga mampu mengatasi dan menyelesaikan permasalahan yang dihadapi dalam dunia kerja $\neg$ nya dan kehidupan sehari-hari. Kemampuan pemecahan masalah pada konsep titrasi mahasiswa masih rendah untuk level submikroskpis (Sari \& Seprianto, 2018)

Mata kuliah Analisis Senyawa Kimia menggunakan kolaborasi antara teori dan praktikum. Selama ini kegiatan perkuliahan cenderung bersifat prosedural dan kurang memberikan kesempatan kepada ma $\neg$ hasiswa untuk berperan aktif. Sehingga diperlukan cara untuk mengetahui tingkat kemampuan pemecahan masalah dalam mengerjakan soal pada materi titrasi.

\section{METODE}

Kemampuan pemecahan masalah pada mahasiswa calon guru IPA diidentifikasi berdasarkan hasil mengerjakan soal titrasi yang diberikan kepada 44 mahasiswa semester 4 tahun akademik 2018/2019 sebanyak 44 mahasiswa program studi pendidikan IPA. Metode menggunakan analisis kuantitatif deskriptif. Data diperoleh dengan melalui tes essay tentang titrasi menggunakan sistematika dari Polya yang meliputi memahami masalah, merencakan strategi penyelesaian, melaksanakan rencana dan mengevaluasi pelaksanaan.

\section{HASIL DAN PEMBAHASAN}

Secara keseluruhan tingkat kemampuan pemecahan masalah mahasiswa dalam menyelasaikan soal titrasi dijabarkan dalam tabel 1

Tabel 1. Kemampuan pemecahan masalah mahasiswa dalam penyelesaian soal titrasi

\begin{tabular}{ccc}
\hline No. & Kriteria & Persentase \\
\hline 1 & Sangat baik & $9 \%$ \\
2 & Baik & $16 \%$ \\
3 & Cukup & $32 \%$ \\
4 & Kurang & $34 \%$ \\
5 & Sangat kurang & $4 \%$ \\
\hline
\end{tabular}

Kemampuan pemecahan masalah calon guru IPA berdasarkan hasil jawaban soal titrasi dengan indikator Polya disebutkan dalam tabel 2

Tabel 2. Hasil Jawaban Mahasiswa Pada Soal Titrasi Dengan Indikator Polya

\begin{tabular}{ccccrrc}
\hline No. & Indikator Polya & Sangat baik & Baik & Cukup & Kurang & Sangat Kurang \\
\hline 1 & Memahami masalah & $18 \%$ & $19 \%$ & $26 \%$ & $24 \%$ & $13 \%$ \\
2 & Merencanakan solusi & $14 \%$ & $15 \%$ & $30 \%$ & $26 \%$ & $15 \%$ \\
3 & Melaksanakan solusi & $12 \%$ & $19 \%$ & $27 \%$ & $30 \%$ & $12 \%$ \\
4 & Mengevaluasi & $9 \%$ & $16 \%$ & $32 \%$ & $28 \%$ & $15 \%$ \\
\hline
\end{tabular}


Rendahnya hasil tes kemampuan pemecahan mahasiswa karena mahasiswa menyatakan sulit dalam analisis titrasi terutama dalam perhitungan yang melibatkan reaksi kimia. Mahasiswa juga belum mampu menganalisis soal dengan baik sehingga tidak mampu menyelesaikannya secara benar. Mahasiswa merasa bingung ketika harus menyelesaikan soal yang melibatkan lebih dari satu reaksi. Beberapa alasan yang dikemukakan mahasiswa terkait dengan kesulitan yang dialaminya antara lain: (1) penyelesaian soal terlalu panjang; (2) sulit dalam menganalisis soal; (3) mata kuliah Analisis Senyawa Kimia memerlukan analisis dan pemahaman yang tinggi; dan (4) kurang mengerjakan latihan soal karena mahasiswa hanya fokus pada materi yang diberikan oleh dosen sehingga belum dapat melakukan perkuliahan untuk mengembangkan keterampilan berpikir tingkat tinggi mahasiswa. Perkuliahan lebih ditekankan pada penguasaan konsep sehingga ketika mahasiswa diberi soal yang menuntut kemampuan problem solving menunjukkan hasil yang rendah (5) mahasiswa belum terampil dalam mencari literatur dan menyalurkan idenya baik secara tertulis maupun lisan.

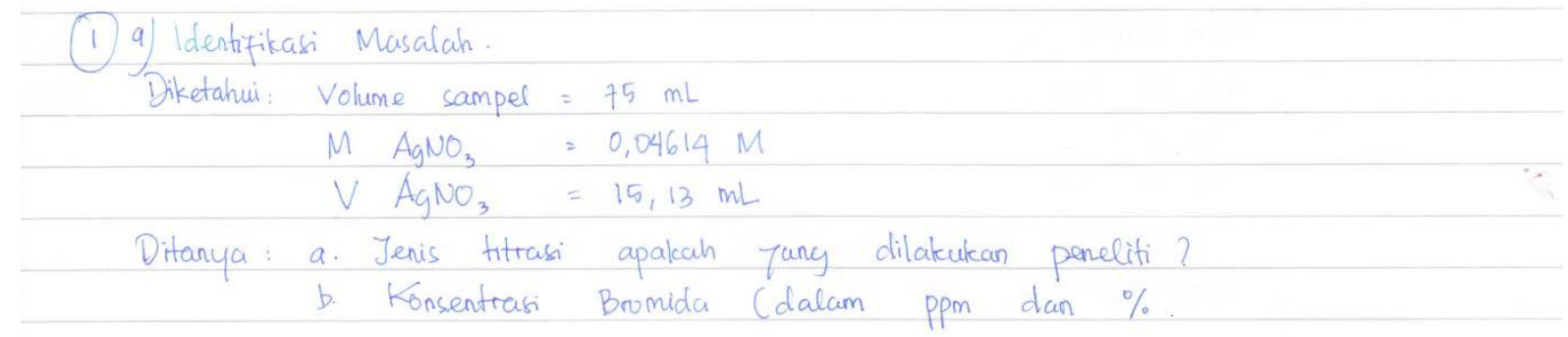

Gambar 1. Contoh jawaban mahasiswa untuk identifikasi masalah

Berdasarkan hasil penelitian maka untuk salah satu upaya untuk meningkatkan kemampuan pemecahan masalah memperbaiki pemahaman konsep mahasiswa perlu dirancang suatu program perkuliahan pada materi analisis kuantitatif yaitu analisis titrimetri berbasis problem solving melalui open-ended experiment. Pemberian open-ended experiment memberikan kesempatan pada mahasiswa untuk melakukan problem solving menggunakan metode yang mirip dengan inkuiri ilmiah yang sesungguhnya (Charen, 1963). Pada saat memecahkan masalah, mahasiswa perlu mentransfer pengetahuan yang dimilikinya ke konteks masalah yang dihadapi. Berdasarkan wawancara dengan beberapa mahasiswa terungkap mahasiswa merasa telah memahami teori dengan baik namun ketika menyelesaikan soal-soal ujian banyak mahasiswa yang tidak dapat menjawabnya dengan benar. Ini berarti bahwa mahasiswa belum belajar secara bermakna, baru sekedar belajar menghafal atau rote learning (Anderson, dkk, 2001) sehingga pemahamannya hanya bersifat sesaat dan mudah lupa.

Rendahnya hasil tes pemecahan masalah ini disebabkan masih banyak mahasiswa yang belum mampu menganalisis dan memecahkan soal dengan baik terutama pada soal yang kompleks serta memerlukan kemampuan analisis dan problem solving. Hal ini dimungkinkan mahasiswa kurang terlatih dalam menyelesaikan masalah di luar jam perkuliahan dan belum terbiasa melakukan problem solving. Kemampuan problem solving perlu dibekalkan kepada mahasiswa calon guru dan perkuliahan tidak hanya menekankan pada aspek kognitif. Menurut Overtoon dan Potter (2008) terdapat korelasi yang positif antara kognitif mahasiswa dengan kemampuan problem solving serta mahasiswa merasa lebih senang dan berpeluang untuk terlibat aktif dalam pembelajaran. Keberhasilan mahasiswa dalam problem solving ditentukan oleh tiga variabel kognitif yaitu pengetahuan utama; hubungan (keterkaitan konsep dan penggabungan ide); dan keterampilan memaknai problem (Lee, dkk, 2001).

Pemecahan masalah dilakukan melalui beberapa tahapan yang dilakukan secara sistematis. Ada berbagai tipe peserta didik dalam menyelesaian masalah antara lain scientific approach, plug and chug, memory based approach dan no clear approach. Berdasarkan teori belajar konstruktivisme Vigotsky menyatakan bahwa proses konstruktivisme dengan menemukan dan membangun pengetahuan 
konsep yang telah mereka pelajari yang dapat mengembangkan pemahaman tentang konsep yang dipelajari.

\section{KESIMPULAN}

Kemampuan pemecahan masalah mahasiswa masih harus ditingkatkan dengan memberikan latihan dan pemberian model pembelajaran yang mampu meningkatkan kemampuan pemecahan masalah mahasiswa.Diperlukan penelitian lebih lanjut untuk mengetahui model pembelajaran yang sesuai untuk meningkatkan kemampuan pemecahan masalah dan kategori jenis pemecahan masalah yang dimiliki oleh mahasiswa. Tujuan dari penerapan problem solving adalah untuk meningkatkan kemampuan kognitif dalam prinsip dan pengembangan konsep.

\section{DAFTAR RUJUKAN}

Anderson, L. W.et.al. 2001. A Taxonomy for Learning, Teaching, and Assessing. A Revision of Bloom's Taxonomy of Educational Objectives. New York: Longman

Agnihotri, A.K, 2015. Problem Solving Ability Among Senior Secondary School Students of Himachal Pradesh. International Journal of Multidiciplinary Research and Development , 2 (2):511—517.

Charen, G. 1963. The Effect of Open-Ended Experi $\neg$ ments in Chemistry on the Achievment of Cer $\neg$ tain Objectives of Science Teaching. Journal of Research in Science Teaching, 1: 184-190

Chun Yen Chang\& Yu Hua Weng.2010. An exploratory study on student's problem solving ability in earth science. International Journal of Science Education, 24 (5):441 - 451

Davis, D.D., McDuffi., A.R., Drake.,C\&Seiwell., A.L 2019. Teachers'perceptions of the official curriculum: Problem solving and Rigor: International Journal of Educational Research (93). 91-100.

Hidayati, Y., Rosidi, I., \& Hadi, W.P 2019. The Indentification Problem Solving Abilities Based on Gender: Implementation Teaching Science Through Guided Discovery Model's in Bangkalan District The 2nd Annual International Conference on Mathematics and Science Education. Journal of Physics Conference Series . 1227/012039 . https://doi.org/10.1088/1742-6596/1227/1/012039

Kuang, C.Y., Azu, C.F \&Ken, Y.L. Enhancing Students' Problem Solving Skills Through Context Based Learning International Journal of Science and Mathematics Education

$$
\text { 13: } 1377-1401
$$

Lee, K.W.L. et al. 2001. The Predicting Role of Cogni $\neg$ tive Variable in Problem Solving in Mole Con $\neg$ cept. Chemistry Education Research and Practice in Europe, 2: 285-301

Nasriah, L. 2017. Problem Solving Methods To Improve Understanding Of Learning Social Subject Matter For Students Of VII Of SMP Negeri 2 Tigaraksa, Indonesia. Europan of Education Studies,3(4):216-222

Nikat, R.L. 2018. The Evaluation Of Physics Students' Problem-Solving Ability Through Mauve Strategy (Magnitude, Answer, Units, Variables, And Equation). People: International Journal of Social Sciences, 3 (3); 1234-1251

Nugroho, A.R. 2018. HOTS : Kemampuan Berpikir Tingkat Tinggi: Konsep, Pembelajaran, Penilaian dan Soal-Soal. Jakarta:PT Gramedia

Nurita, T., Hastuti., P.W.\& Sari., D.A.P. 2017. Problem Solving Ability of Science Students in Optical Wave Course . Jurnal Pendidikan IPA Indonesia, 6 (2):341-345.

Overtoon, T. \& Potter, N. 2008. Solving Open-ended Problems and Influence of Cognitive Factor on Students Success. Chem. Educ. Res. Pract, 9: 65-69

Polya, G. 1945. How to Solve I: A New Aspect of Mathematical Method. New Jersey: Princeton University Press 
Sumarni, W., Wijayati, N., \&Supanti, S. 2019. Kemampuan Kognitif dan Berpikir Kreatif Siswa Melalui Pembelajaran Berbasis Proyek Berpendekatan STEM. Jurnal Pembelajaran Kimia, 4 (1):18—30

Widyasari, N., \& Rosiyanti, H. 2019. Developing material for promoting problem solving ability through bar modeling technique. ICE-STEM. Journal of Physics Conference Series. 948012055. https://doi.org/ 10.1088/1742-6596/948/1/012055

Wismath, S., Orr, D\& Zhong, M.2014. Student Perception of Problem Solving Skills. Transformative Dialogues: Teaching\&Learning Journal, 7 (3):441—451

Wlas, L.N., Howard, R.G., \&Biwe, B. 2007. Phenomenographic study of students' problem solving approaches in physics. Physical Review Special Topics - Physics Education Research 3 